\title{
NEW CHALLENGES IN INCOTERMS IN THE BACKGROUND OF THEIR HiSTORICAL DEVELOPMENT
}

\author{
Michaela Petrová $^{1}$; Martina Krügerová ${ }^{2}$; Michal Koziel ${ }^{3}$ \\ VŠB - Technical University of Ostrava, Faculty of Economics, Department of Law, \\ 17. listopadu 2172/15, 70800 0strava-Poruba, Czech Republic \\ e-mail: ${ }^{1}$ michaela.petrova@ vsb.cz; ${ }^{2}$ martina.krugerova@ vsb.cz; ${ }^{3}$ michal.koziel@ vsb.cz
}

\begin{abstract}
INCOTERMS conditions are internationally recognized delivery clauses. Their advantage is comprehensibility and uniform interpretation by the contracting parties, as well as easy incorporation into the contract. An undeniable advantage is the regular update. The individual updates reflect trends in international business practice and therefore clarify or repeal existing clauses or introduce new ones as needed. The aim of the article is to evaluate the development of the INCOTERMS clauses on their historical development and their impact on international commercial law relations, and through this to outline possible future developments. The authors also consider whether, given the rapid technological progress, the current ten-year cycle of revision of the INCOTERMS clauses is appropriate or whether it is too long. Among the new trends, the authors point to new types of transport, especially unmanned drones, and the continuing trend of a transparent and secure logistics chain.
\end{abstract}

\section{Keywords}

Autonomous transport; Blockchain; Drones; Incoterms; International trade; Technology.

\section{Introduction}

Central to commercial transactions concluded in the framework of international trade is the issue of passing the risk of accidental destruction and destruction of goods. Entrepreneurs in this area can use two ways that can greatly simplify the contracting process for the international purchase of goods, as well as possible undesirable problems in the future. The first is the United Nations Convention on the International Sale of Goods (CISG), or the Vienna Convention, which regulates these issues indirectly. Furthermore, International Commercial Terms (INCOTERMS), i.e., rules that individual parties can incorporate themselves into contracts in commercial transactions. Incoterms are an acronym for INternational COmmercial TERMS.

The rules of Incoterms have been defined and are constantly being developed by practitioners associated in the International Chamber of Commerce ICC, which was established in 1919 in Paris to promote greater openness of national markets for foreign trade and investment. The International Chamber of Commerce (ICC) published the first version of the Incoterms for establishing generally accepted definitions and rules for the delivery of goods between seller and buyer as early as 1936. Awareness of Incoterms gradually spread among entrepreneurs and very quickly became internationally recognized delivery clauses, without the knowledge of which the entrepreneur can no longer do without concluding a purchase contract. Thanks to these rules, entrepreneurs can avoid the uncertainty resulting from different interpretations of the method of delivery of goods and the transfer of risks and costs from seller to buyer, without complicating the extension of the agreement on these issues, as the abbreviations replace to this extent. The Incoterms are applicable to both international and domestic trade. 
The first Incoterms were valid for only 13 countries. They are now used in more than 140 countries and are translated into 31 different languages. At present, there are a total of 11 commercial clauses in Incoterms 2020 divided for any mode of transport (EXW, FCA, CPT, CIP, DAP, DPU, DDP) and for sea and inland waterway transport (FAS, FOB, CFR, CIF).[1] With the conditions of FCA, DAP, DPU and DDP, it is now possible to secure transport with the seller's or buyer's own means. Because the Incoterms are drafted in detail in many languages and are widely available, even a layman is able to understand from these rules and their explanations what rights and obligations apply to him when choosing a particular clause. This alone can be seen in the importance of Incoterms for world trade.

Incoterms have the character of business conditions, they do not replace the contract, they only supplement it. This means that, if permitted by law, they replace or supplement statutory provisions. The advantage of Incoterms is their comprehensibility and uniform interpretation between the contracting parties, which eliminates possible disputes regarding the interpretation of individual provisions of the contract, which are replaced by these international rules.[2] The actual implementation of the conditions into the contract follows a simple formula [1]: "[the chosen Incoterms ${ }^{\circledR}$ rule] [named port, place or point] Incoterms 2020 ". The chosen Incoterms ${ }^{\circledR}$ rule means the three-letter term of the clause. Also, the named port, place or point, is extremely important to clearly specify. For all Incoterms ${ }^{\circledR}$ rules, except for group $\mathrm{C}$, this place indicates where the goods are to be "delivered" (ie where the risk passes from the seller to the buyer). For Group D rules, this place is both the place of delivery and the place of destination, and the seller must arrange transport up to this point. For Group $\mathrm{C}$ rules, this place indicates the destination of the consignment, ie the point to which the seller must arrange transport at his own expense (this point, however, does not coincide with the place or port of delivery). Therefore, it is important to mark the place with the most accurate geographical information, and the use of GPS coordinates is not excluded. Versioning avoids the problem of clearly determining which version of the rules applies to a given purchase agreement. The advantage of Incoterms is therefore their comprehensibility, uniform interpretation between the parties, which eliminates any disputes regarding the interpretation of individual provisions of the contract, which are replaced by these international rules, as well as their simple incorporation into the contract.

Like most industries, international trade is changing. Whether it is transport, payment conditions, innovations in the process of contracting contracts, technological development, everything is gradually reflected in the contractual conditions and in business legal relations. And in the final stage, changes in business practice are incorporated into the Incoterms. The changes in the Incoterms rules can also be used to demonstrate the development of the world economy and trade. The current version of INCOTERMS 2020 entered into force on 1 January 2020. It is thus the eighth revision of international rules, and thus the ninth edition of the conditions.

The concept of the article is based on the conference paper of the conference Liberec Economic Forum 2021 [24] and the discussion within this conference.

\section{$1 \quad$ Research Objectives}

The aim of the article is to evaluate the development of the INCOTERMS clauses on their historical development and their impact on the international commercial law relationship, and through this to outline possible future developments. The authors identify trends that currently affect or will certainly affect international trade relations and their possible implementation in the current INCOTERMS conditions, i.e., whether the current INCOTERMS business conditions respond to these new trends or whether their change is already necessary. 
The issue of Incoterms is given great attention in research. We can also look at delivery conditions from different angles. For example, Vogt a Davis [3] divided scientific articles into four areas: in terms of a general description of Incoterms' delivery terms, comparisons of individual versions of Incoterms or individual delivery clauses, the third area is the legal view, i.e., the inclusion of clauses in business cases. The last area (fourth) is the contributions that deal with the lack of understanding of the rules. Still, let's add more views. Incoterms can be considered a risk management as an effective tool for risk management. [4], [5]. [6] on the other hand, considers delivery rules to be a kind of "channel" that connects trade and logistics.

However, from all points of view, the basic purpose of these conditions can be traced, namely, to help entities determine their mutual roles, duties, and responsibilities in international trade. This will provide the parties with the certainty of a uniform interpretation of the clause included in the specific contract. The authors agree that the correct use of the clauses can speed up logistics for parties and bring cost savings [1], [3], [7], and to simplify and make accessible the link between logistics and trade in general [6].

But let's get back to the beginning. The tradition of using trade terms and incorporating them into contracts began in Great Britain in the nineteenth century. They were founded by experts associated in the ICC International Chamber of Commerce, whose goal is to support the development of the world economy by developing international trade, services and investment and removing their barriers (in more detail [8], [9]). Incoterms was first published in a codified edition in 1923 [10] and contained six conditions. This standardization has fostered international trade, but there have been significant differences in the interpretation of trade conditions between countries and sectors [11]. That is why the ICC proposed in 1936 to publish a publication of the International Terms and Conditions with the aim of a uniform interpretation of the terms and conditions. As it states [11] traders could thus rely on a uniform interpretation of the condition included in the purchase agreement. Incoterms have gradually become internationally recognized delivery clauses, which are almost a matter of course when concluding an international purchase agreement. The reason is also their comprehensibility. [7]. The ICC's Incoterms rules are reviewed and revised at more or less regular intervals; in the last forty years, they have been updated every ten years. The updates mainly reflect changes in international trade and supply rules. When referring to a specific clause, it is important to indicate the Incoterms version to avoid ambiguity in the version of the condition used. [10] states that it is especially important during the transitional period, when a new revision is issued. The last revision, i.e., the release of Incoterms, is from the year 2020.

Regular updates reflect changes in business practice and technological progress, but must also respond to societal developments, sustainable business, corporate social responsibility and increasing pressure to protect the environment. We can predict that the relatively rapid development in alternative modes of transport will also affect trade relations. That is, until the next update of the Incoterms conditions. The changes will affect all types of transport, autonomous vehicles in the case of road transport, autonomous vessels in the case of waterborne transport or drones in the case of air transport. Trends in transport and the use of electric vehicles, autonomous vehicles and combined electric freight transport are being studied by [12]. [13] and [14] analyze the possible use of drones in transport, [15] then describes the legal aspects of the issue of drones at the level of experts from the business environment, representatives of academia and experts or expert groups of research institutes. Although drones are still limited by battery life and therefore range, they can be considered the music of the future in the transport of goods [16]. In the next decade, the transport of goods will undergo fundamental changes, which will certainly be reflected in the conditions 
of Incoterms. Because the innovations bring new legal risks, changes in the insurance approach and new risks due to the safety of technological innovations.

\section{$3 \quad$ Methods and Data Collection}

The source of data needed to compile an overview of the historical development of individual versions of the Incoterms conditions is directly the information published by the International Chamber of Commerce and the individual versions of the given Incoterms. The research period is from the first conditions from 1923 to the last version of Incoterms 2020. Subsequently, the authors analyzed the key developments in selected areas, which are reflected in the conditions of Incoterms and, according to the authors, will need to be reflected in future versions. The methods of scientific work based on the evaluation of primary and secondary data, induction and deduction, analysis and synthesis are used.

\subsection{Development and Overview of Changes in Incoterms}

At the beginning of the whole process of creating Incoterms rules stood the entrepreneurs themselves - such as industrialists, financiers, and traders, who decided to create an industry standard after the First World War precisely because of the absence of a global system of rules for business management. The first common terms and conditions were issued by the International Chamber of Commerce [8] in 1923, but the first official released version of Incoterms is from 1936. Over the years, there were individual revisions of the clauses, but also the rules were extended to other countries. The first terms were used in 13 countries, the eighth revision is used by traders in 140 countries and is translated into a total of 31 languages. Table 1 provides an overview of the clauses in the individual versions of Incoterms.

Tab. 1: Incoterms versions

\begin{tabular}{|l|l|l|l|l|l|l|l|l|l|l|l|l|l|}
\hline & $\begin{array}{l}\text { Group } \\
\text { E }\end{array}$ & \multicolumn{3}{|c|}{ Group F } & \multicolumn{4}{|c|}{ Group C } & \multicolumn{5}{c|}{ Group D } \\
\hline $\mathbf{1 9 3 6}$ & - & - & FAS & FOB & C\&F & CIF & - & - & $\begin{array}{l}\text { Ex } \\
\text { Ship }\end{array}$ & $\begin{array}{l}\text { Ex } \\
\text { Quay }\end{array}$ & - & - & - \\
\hline $\mathbf{1 9 5 3}$ & - & - & FAS & $\begin{array}{l}\text { FOB/FOR } \\
\text { /FOT }\end{array}$ & C\&F & CIF & - & DCP & $\begin{array}{l}\text { Ex } \\
\text { Ship }\end{array}$ & $\begin{array}{l}\text { Ex } \\
\text { Quay }\end{array}$ & - & - & - \\
\hline $\mathbf{1 9 6 7}$ & - & - & FAS & $\begin{array}{l}\text { FOB/FOR } \\
\text { /FOT }\end{array}$ & C\&F & CIF & - & DCP & $\begin{array}{l}\text { Ex } \\
\text { Ship }\end{array}$ & $\begin{array}{l}\text { Ex } \\
\text { Quay }\end{array}$ & DAF & - & DDP \\
\hline $\mathbf{1 9 7 6}$ & - & - & FAS & $\begin{array}{l}\text { FOB/FOR } \\
\text { /FOT/ } \\
\text { FOB } \\
\text { Airport }\end{array}$ & C\&F & CIF & - & CPT & $\begin{array}{l}\text { Ex } \\
\text { Ship }\end{array}$ & $\begin{array}{l}\text { Ex } \\
\text { Quay }\end{array}$ & DAF & - & DDP \\
\hline $\mathbf{1 9 8 0}$ & - & FRC & FAS & $\begin{array}{l}\text { FOB FOT/ } \\
\text { FOB } \\
\text { Airport }\end{array}$ & C\&F & CIF & - & CPT & $\begin{array}{l}\text { Ex } \\
\text { Ship }\end{array}$ & $\begin{array}{l}\text { Ex } \\
\text { Quay }\end{array}$ & DAF & - & DDP \\
\hline $\mathbf{1 9 9 0}$ & EXW & FCA & FAS & FOB & CFR & CIF & CIP & CPT & DES & DEQ & DAF & DDU & DDP \\
\hline $\mathbf{2 0 0 0}$ & EXW & FCA & FAS & FOB & CFR & CIF & CIP & CPT & DES & DEQ & DAF & DDU & DDP \\
\hline $\mathbf{2 0 1 0}$ & EXW & FCA & FAS & FOB & CFR & CIF & CIP & CPT & - & DAT & DAP & - & DDP \\
\hline $\mathbf{2 0 2 0}$ & EXW & FCA & FAS & FOB & CFR & CIF & CIP & CPT & - & DAT & DAP & - & DDP \\
\hline
\end{tabular}

Source: Own based on [8] and [19] 


\subsubsection{Pre-INCOTERMS Edition 1923}

Shortly after World War I, it was clear to the founders of the ICC that international trade should not be regulated by governments, but by private industry through uniform global standards. [3]. Therefore, as early as 1920, the first negotiations for the creation of common business conditions began. It was a study [8] of six commonly used terms in thirteen countries. A summary of the findings, and especially of the differences in interpretation, was published in 1923.

\subsubsection{Pre-INCOTERMS Edition 1928}

The version of the terms and conditions from 1928 underwent changes concerning the elimination of errors and clarification of the original version from 1923. The first survey identified a number of shortcomings, but the second study succeeded in remedying them and applying common business conditions to more than 30 countries.[8]

\subsubsection{INCOTERMS 1936}

We can speak of the 1936 version as the first official version of Incoterms. It consisted of six terms - FAS (Free Alongside Ship), FOB (Free on Board), C\&F (Cost \& Freight), CIF (Cost Insurance and Freight), Ex Ship (Delivered Ex Ship) and Ex Quay (Delivered ex Quay). [8] For the first time, there has been a uniform adjustment of procedures in international trade.

\subsubsection{INCOTERMS 1953}

The further development of Incoterms was influenced by the Second World War, due to which additional revisions of the rules were suspended. Therefore, the Incoterms were first changed in 1953, mainly due to the increase in rail traffic. In addition to the original six rules, three more rules have been added for non-maritime transport - DCP (Delivered Costs Paid), FOR (Free on Rail) and FOT (Free on Truck). [8]

\subsubsection{INCOTERMS 1967}

The 1967 version of the Incoterms corrected misinterpretations of the previous 1953 version. This revision was the third in a row and added two new terms - DAF (Delivery at Frontier) and DDP (Delivery at Destination). [8]

\subsubsection{INCOTERMS 1976}

Air transport was included in the group of Incoterms business conditions in 1976, specifically the FOB Airport (Free on Board Airport) condition. The FOB condition itself appeared in the first official version of Incoterms, where, however, it was typical for maritime transport. [8]

\subsubsection{INCOTERMS 1980}

The 1980 version of Incoterms was related to the expansion of container traffic and new documentation processes, which required further revision, which resulted in a new condition FRC (Free Carrier... Named at Point). [8]

\subsubsection{INCOTERMS 1990}

The main reason for creating the new version of Incoterms 1990 was the need to adapt the clauses to the increasing use of electronic data interchange (EDI) and adaptation to intermodal transport. In the new version, the FCA clause has been modified to suit all modes of transport, even in various combinations. As a result, clauses have been omitted which only concerned 
certain types of transport, namely FOR, FOT and FOB Airport. In connection with the revision work, Incoterms were organized into four groups and 13 clauses:

- group E - withdrawal clause (EXW),

- group F - main freight unpaid (FCA, FAS, FOB),

- group C - main freight paid (CFR, CIF, CPT, CIP),

- group D - delivery clauses (DAF, DES, DEQ, DDU, DDP). [17]

\subsubsection{INCOTERMS 2000}

The revision process for the new edition of Incoterms 2000 took approximately two years. The International Chamber of Commerce in Paris sought responses, opinions or suggestions for improvement from a wide range of global traders. At the same time, it also sought to ensure that the wording of the Incoterms 2000 terms and conditions reflected business practice. Another reason was the changes in transport techniques, especially in connection with the development of containerization, combined transport, and the introduction of new technologies in transport. The changes were made in the area of customs, specifically in the area of customs clearance and payments of customs obligations under the FAS and DEQ, and then in the area of loading and unloading obligations under the FCA. Compared to Incoterms 1990, the individual conditions did not change, nor did their arrangement into four groups. Thus, changes can only be understood as the above-mentioned specification of formulations. [18]

\subsubsection{INCOTERMS 2010}

The Incoterms 2010 version consolidated the Group D clauses. The DAF, DES, DEQ and DDU conditions have been replaced compared to the Incoterms 2000 version by the new DAT (Delivered at Terminal) and DAP (Delivered at Place) rules, which can be used regardless of the agreed mode of transport. The number of conditions was reduced from thirteen to eleven. Furthermore, the Incoterms 2010 rules were newly divided into two classes, namely rules for all modes of transport and rules for maritime and inland waterway transport. The first group includes the conditions EXW, FCA, CPT, CIP, DAT, DAP, DDP and the second group FAS, FOB, CFR, and CIF. [19]. Transport safety was also addressed, as well as wording facilitating the use of electronic means of communication. Already in the INCOTERMS 1990 version, the replacement of classic paper documents by electronic data transmission was predicted. [2] In the 2010 revision, electronic data transmission is already considered a completely common, everyday practice.

Previous versions of the rules, i.e., issued before 2010, were classified into four groups, namely E, F, C and D, where E and D were located at the farthest points apart from the place of delivery, while F and C were located between them. Since 2010, the Incoterms rules have been classified according to the type of transport into two classes (Table 2). Nevertheless, the original division can be an aid to understanding the significance of the place of delivery.

Tab. 2: Incoterms version-type of transport

\begin{tabular}{|l|l|l|l|l|l|l|l|l|l|l|l|l|}
\hline & \multicolumn{4}{|c|}{ Rules for all modes of transport } & \multicolumn{4}{c|}{$\begin{array}{c}\text { Rules for maritime and } \\
\text { inland waterway transport }\end{array}$} \\
\hline $\mathbf{2 0 1 0}$ & EXW & FCA & CPT & CIP & DAT & DAP & DDP & CPT & FAS & FOB & CFR & CIF \\
\hline $\mathbf{2 0 2 0}$ & EXW & FCA & CPT & CIP & DPU & DAP & DDP & CPT & FAS & FOB & CFR & CIF \\
\hline
\end{tabular}

Source: Own based on [8] and [19] 


\subsubsection{INCOTERMS 2020}

Currently, the most current version is Incoterms 2020. The impetus for the changes was, on the one hand, the effort to link the rules as much as possible with practice, but also to facilitate the correct choice of the clause. For the new version, it was important to focus on improving the presentation so that users would be directed to the right rule for their contract. Therefore, cosmetic changes have been made which should lead to smoother export / import transactions. This is a clearer explanation of the definition and connection between the purchase contract and the supplementary contracts, with explanations for each rule and the possibility of re-ordering in accordance with the rules. In Incoterms 2020, there is a change in the name of the DAT (Delivered at Terminal) condition to DPU (Delivered at Place Unloaded). Also new is that the FCA condition will allow the issuance of a consignment note with on-board registration. The conditions of CIF and CIP were also changed, which sets new insurance standards. Incoterms 2020 also offers explanations for users to make working with clauses as simple as possible and the use of these terms and conditions in practice as userfriendly as possible. [1] The result is 11 commercial clauses divided by type of transport - for any mode of transport (EXW, FCA, CPT, CIP, DAP, DPU, DDP) and for sea and inland waterway transport (FAS, FOB, CFR, CIF).

\subsection{Modifications to Incoterms}

The rules of Incoterms have been clearly defined over the years and reflect the business practice of selling and buying goods. They describe, as we have already stated, the obligations of the buyer and seller parties, clearly set out the transfer of risk between the parties, and determine which party is responsible for what costs. Even so, there may be a case where the parties need to modify the Incoterms rule. In such a case, it is necessary to specify such a change as clearly as possible. The express provisions in the purchase contract take precedence over the provisions in INCOTERMS [20]. If Incoterms respond in a timely manner to changes in developments and business practices, the need for individual changes will be lower.

\section{INCOTERMS - New Challenges}

The aim of Incoterms is to provide the contracting parties with an advantage in the form of a uniform interpretation of the terms and conditions, clear comprehensibility, and the applicable applicability according to a set formula. It is for these reasons that Incoterms are the most widely used in international trade. [7]. However, in order for the contracting parties not to have to modify the rules, it is desirable that the rules be not only interchangeable, but also correspond to commercial and legal practice. Since its first introduction in 1936, Incoterms have been gradually evolving and responding to changes in international trade, progress, and changes in the logistics chain. Significant updates are due to the development of transport and their priorities. The expansion of rail transport was the reason for the revision in 1953. Air transport was reflected in the changes in 1976. The expansion of container transport together with new documentation processes required a change in 1980. That is, 4 years after the last revision. In 1990, the clauses were reviewed as they proved inflexible. The clauses had to be adapted to a new trend - intermodal transport. Intermodal transport combines the advantages of individual transports and increases overall efficiency. An equally important factor is the lower environmental burden of intermodal transport. In the coming years, the clauses will be revised in line with the introduction of new technologies in transport, the development of containerization and intermodal transport. The year 2010 and 2020 were also marked by socalled cosmetic changes. The rules were newly divided into two classes, namely rules for all modes of transport and rules for maritime and inland waterway transport. The latest revisions 
reflect an element of flexibility in technology innovations, ease of use and comprehensibility, all in the spirit of current business practice.

The last revision of the clauses is from 2020 and after one year critical opinions are being expressed. In their article [21], they concluded that even after the release of the new version of Incoterms 2020, the rules remain ambiguous in many cases and tend to be simplified. [22] in their study they point to innovations in technology, means of payment, artificial intelligence, and robotics. With the development of e-commerce, automated systems will be developed that are and will be able to select the most suitable conditions for a given business case. Also [23] states that digitization or the issue of security is insufficiently mentioned and regulated in the new clauses. Experts have also been seeing the Ex Works clause for a long time, calling for it to be amended or repealed, but unfortunately this has not happened.

As we can see from the development of clauses and individual revisions, technological progress is a major driver for change or the creation of new clauses. We already know that at the time of the next revision (i.e. in 2030) there will be technologies that were not yet fully used before. Technological developments are also reflected in production processes and logistics. Drones generally have great potential in transport. Therefore, even Incoterms should go in this direction. The use of autonomous means of transport is linked to the management of overall logistics in line with more efficient use of means of transport and sustainability. However, the reduction of damage caused by an autonomous means is problematic. On the one hand, the damage caused by the person operating the means of transport will be reduced, but new damage will arise in connection with the autonomous regime. In the event of such damage, it will be more difficult to prove the relevant liability. And it is precisely liability for damage caused by the operation of autonomous funds and, at the same time, insurance will have to be reflected in the contractual conditions.

Drones are therefore one of the main challenges for further revision of the clauses. Their advantages are the range to inaccessible areas and less involvement of the human factor. In addition to increasing transport safety, the necessary breaks are also eliminated by removing the human factor, thus speeding up overall traffic. Equally important is the social responsibility of currently using drones to use electric propulsion [16]. At the same time, in the case of drone transport, it is necessary to assume that there will be a revolution in logistics chains, when the existing logistics centers will be gradually reduced or even abolished. If the current technological obstacles, especially in the current low range of drones, can be overcome, several links in the logistics chain may be skipped, when the drone logistics center will be able to serve many clients over a very large area. However, only practice will show to what extent drones will be able to replace existing modes of transport.

However, we must not forget the technical provision of international trade and developments in this area. A blockchain has become internationally known, the possibilities of which go far beyond cryptocurrencies. It can be used, for example, in securing international business transactions, where it would be possible to clearly identify the place of origin thanks to the blockchain. However, all these new ways in which international trade could continue to develop have one major shortcoming, and that is the fact that there is currently no legal framework for them to be able to use them without much risk. And this is where INCOTERMS is offered as an ideal means of unifying or implementing these rules. Why not use the international recognition and acceptance of these clauses for the implementation of rules in other areas.

The last two years have also shown that the INCOTERMS rules now face a very difficult challenge. The whole world is currently facing the consequences of the COVID-19 pandemic, which is affecting trade-supplier relations in international trade to an unprecedented extent. 
Unfortunately, the last revision of the INCOTERMS rules took place before the COVID-19 pandemic struck in full. However, over the last two years, we have witnessed, and still witness, how these clauses are being tested daily in conditions that were unthinkable a few years ago. In view of the fact that the international community will respond to the current situation by changing the INCOTERMS clauses only in 2030, it is definitely worth considering whether to speed up the whole process of updating them, even in the light of what has been said in this article. Here, however, we find ourselves in a very sensitive area, where, in addition to the requirement for topicality, stability is especially important in law. And it would certainly not benefit this stability if the INCOTERMS clauses were changed here, for example, every two years.

\section{Conclusion}

The Incoterms delivery conditions are currently the most used conditions, as evidenced by the ICC's care in the form of revisions, extensions, or refinements. The individual revisions, as described in the article, respond to the development of the global economy, as well as to the demands and habits of participants in international trade. Revisions are necessary and desirable, as obsolete clauses would not be used by participants. Incoterms thus becomes an effective tool for participants in resolving situations arising in international trade. Their use is already considered a standard, as evidenced by their spread across countries or sectors. Nevertheless, it is always necessary to pay attention to each business case when using clauses, because a carefully selected clause can save the trader a number of problems. This is one of the reasons why the latest revision in 2020 simplified the interpretation and presentation of clauses to make it easier for participants to choose the appropriate clause. It is still necessary to consider that the INCOTERMS delivery clauses do not regulate the legal relations between the buyer and the seller arising by default from the purchase contract, they do not address the transfer of ownership from the seller to the buyer. INCOTERMS are based on the principle of determining the minimum obligations of the parties. The parties may, if they so wish, agree on broader obligations. [20]. The express provisions in the purchase contract take precedence over the provisions in INCOTERMS.

Finally, we summarize the very essence of why the INCOTERMS clauses were introduced. These clauses were primarily intended to facilitate and speed up commercial transactions in international trade but were also intended to provide entrepreneurs with a considerable degree of certainty. Although the current INCOTERMS conditions still bring this, however, by not responding to new challenges, especially in new modes of transport, they leave a great deal of uncertainty to entrepreneurs who are going to use these new modes of transport. Therefore, it is being considered whether these facts should not have been considered in the revision of the clauses in 2020, and therefore the number of clauses or their significance should not be extended to other areas. From the point of view of ten-year revisions, change is also offered. Although the ten-year cycle of clause revision has stabilized since 1980, a more flexible response to changes can be read from the history of development, when in 1980 clauses required revision in connection with the expansion of container transport and new documentation processes (the result was a new FRC condition). The authors therefore believe that due to the rapid development in modes of transport or payment technologies, it will be necessary to carry out a revision before 2030 .

The INCOTERMS clauses are therefore currently facing major challenges associated with both the introduction of new modes of transport and developments in the field of blockchain or the intervention in international trade caused by the COVID-19 pandemic. Although it would be desirable, as the authors mentioned above, for the clauses to be revised before 2030, the authors are also aware that the updating of the clauses is the result of complex 
international compromises. Each country has dealt with the current situation differently, and this will make it very difficult to find further consensus across the international environment.

\section{Acknowledgement}

This research was financially supported within the VŠB-Technical University SGS grant project No. SP2021/74 (Minimization of Risks Related to the Delivery of Goods Against the Background of the Use of INCOTERMS 2020). We thank the co-researchers Varčoková J., Novosadová A., Kovářová V., Zahrajová K. for assistance in obtaining and preparing data.

\section{Literature}

[1] ICC: Free Incoterms ${ }^{\circledR} 2020$ introduction. [online]. 2020. Available from WWW: https://iccwbo.org/publication/incoterms-2020-introduction/

[2] ROZEHNALOVÁ, N.; VALDHANS, J.; KYSELOVSKÁ, T.: Právo mezinárodního obchodu. Včetně problematiky mezinárodního rozhodčího řizení. [online]. Wolters Kluwer, 2021 [accessed 2021-10-13]. ISBN 978-80-7676-046-2. Available from WWW: https://www.muni.cz/vyzkum/publikace/1738163

[3] VOGT, J.; DAVIS, J.: The State of Incoterm ${ }^{\circledR}$ Research. Transportation Journal. 2020, Vol. 59, Issue 3, pp. 304-324. DOI: 10.5325/transportationj.59.3.0304

[4] BERGAMI, R.: Managing Incoterms 2010 risks: tension with trade and banking practices. International Journal of Economics and Business Research. 2013, Vol. 6, Issue 3, pp. 324-338. ISSN 1756-9850. eISSN 1756-9869. DOI: $10.1504 / \mathrm{IJEBR} .2013 .056126$

[5] PETROVÁ, M.; KOZIEŁ, M.; KRÜGEROVÁ, M.: Influence of Incoterms 2020 on Strategic Decision-making of Entrepreneurs. In: Němec, R.; Chytilová, L. (eds.), Proceedings of the 14th International Conference on Strategic Management and its Support by Information Systems 2021. Ostrava: VŠB-TUO, 2021, pp. 248-255. ISBN 978-80-248-4521-0.

[6] STOJANOVIĆ, Đ.; IVETIĆ, J.: Possibilities of using Incoterms clauses in a country logistics performance assessment and benchmarking. Transport Policy. 2020, Vol. 98, pp. 217-228. ISSN 0967070X. DOI: 10.1016/j.tranpol.2020.03.012

[7] SURARAKSA, J.; AMCHANG, Ch.; SAWATWONG, N.: Decision-Making on Incoterms 2020 of Automotive Parts Manufacturers in Thailand. The Journal of Asian Finance, Economics and Business. 2020, Vol. 7, Issue 10, pp. 461-470. DOI: $10.13106 /$ jafeb.2020.vol7.no10.461

[8] ICC: Free Incoterms ${ }^{\circledR} 2020$ introduction. [online]. [accessed 2021-10-06]. Available from WWW: https://iccwbo.org/publication/incoterms-2020-introduction/

[9] KELLY, D.: The International Chamber of Commerce. New Political Economy. 2005, Vol. 10, Issue 2, pp. 259-271. ISSN1356-3467. DOI: $10.1080 / 13563460500144868$

[10] BERGAMI, R.: Incoterms 2010: The Newest Revision of Delivery Terms. Acta Universitatis Bohemiae Meridionales. 2012, Vol. 15, Issue 2, pp. 33-40.

[11] MALFLIET, J.: Incoterms 2010 and the mode of transport: how to choose the right term. In: Management challenges in the $21^{\text {st }}$ century: transport and logistics: opportunity for Slovakia in the era of knowledge economy, Proceedings. 2011, pp. 163179. Available from WWW: https://biblio.ugent.be/publication/1212622 
[12] MONIOS, J.; BERGQVIST, R.: The transport geography of electric and autonomous vehicles in road freight networks. Journal of Transport Geography. 2019, Vol. 80, 102500. ISSN 0966-6923. DOI: 10.1016/j.jtrangeo.2019.102500

[13] HUB. UPS nakoupí elektrické letouny s vertikálním vzletem. Budou sloužit klientům z oblasti zdravotní péče a malým i středním podnikům. Logistika. 2021. [accessed 202107-13]. Available form WWW: https://logistika.ihned.cz/c1-66911230-ups-nakoupielektricke-letouny-s-vertikalnim-vzletem-budou-slouzit-klientum-z-oblasti-zdravotnipece-a-malym-a-strednim-podnikum

[14] YAKUSHIJI, K. et al.: Short-Range Transportation Using Unmanned Aerial Vehicles (UAVs) during Disasters in Japan. Drones. 2020, Vol. 4, Issue 4, p. 68. DOI: $\underline{10.3390 / \text { drones } 4040068}$

[15] FU, Chen-Hua; TSAO Ming-Wen; CHI, Li-Pin; ZHUANG, Zheng-Yun.: On the Dominant Factors of Civilian-Use Drones: A Thorough Study and Analysis of CrossGroup Opinions Using a Triple Helix Model (THM) with the Analytic Hierarchy Process (AHP). Drones. 2021, Vol. 5, Issue 2, p. 46. DOI: 10.3390/drones5020046

[16] GALBIATI, F.: Delivery Optimization of a Logistics Network based on Drones. Young Scientists Journal. 2020 [accessed 2021-08-12]. Available from WWW: https://ysjournal.com/delivery-optimization-of-a-logistics-network-based-on-drones/

[17] ICC: Incoterms 1990. [online]. 2018 [accessed 2021-08-12]. Available form WWW: https://library.iccwbo.org/pdf/Incoterms_1990.pdf

[18] UNITED NATIONS: ICC Incoterms 2000: report of the Secretary-General. [online]. 2020. [accessed 2021-08-12]. Available from WWW: https://digitallibrary.un.org/record/413948? $\ln =\mathrm{en}$

[19] ICC: The Incoterms ${ }^{\circledR}$ rules 2010. [online]. 2010. [accessed 2021-10-15]. Available from WWW: https://iccwbo.org/publication/incoterms-rules-2010/

[20] MACHKOVÁ, H.; ČERNOHLÁVKOVÁ, E.; SATO, A. et al.: Mezinárodní obchodní operace. $6^{\text {th }}$ ed. Praha: Grada, 2014. ISBN 978-80-247-4874-0.

[21] DAVIS, J.; VOGT, J.: Incoterms ${ }^{\circledR} 2020$ and missed opportunities for the next version. International Journal of Logistics Research and Applications. 2021. DOI: $\underline{10.1080 / 13675567.2021 .1897974}$

[22] DURDAĞ, C.; DELIPINAR, G. E.: The past, today and future of incoterms in international delivery: A review on the innovations in logistics. Journal of Economics Library. 2020, Vol. 7, Issue 4, pp. 201-207.

[23] TOMAN, P.: Nové Incoterms 2020 jsou srozumitelnější. Logistika. 2019, Available form WWW: https://logistika.ekonom.cz/c1-66693550-nove-incoterms-2020-jsou$\underline{\text { srozumitelnejsi }}$

[24] PETROVÁ, M.; KRÜGEROVÁ, M.; KOZIEŁ, M.: INCOTERMS - History and Future Development. In: Antlová, K.; Semerádová, T. (eds.), Proceedings of the 15th International Conference Liberec Economic Forum 2021. Technical University of Liberec, Liberec, 2021, pp. 589-598. ISBN 978-80-7494-578-6.

Ing. Michaela Petrová; Ing. Martina Krügerová, Ph.D.; dr. Mgr. Michal Kozieł, Ph.D. 


\section{NOVÉ VÝZVY INCOTERMS NA POZADÍ JEJICH HISTORICKÉHO VÝVOJE}

Podmínky INCOTERMS jsou mezinárodně uznávané dodací doložky. Jejich výhodou je srozumitelnost a jednotná interpretace smluvními stranami, a také jednoduché začlenění do smlouvy. Nespornou výhodou je i pravidelná aktualizace. Jednotlivé aktualizace odrážejí trendy v mezinárodně obchodní praxi a podle potřeby tedy upřesňují či ruší stávající doložky nebo zavádí nové. Cílem článku je na historickém vývoji doložek INCOTERMS zhodnotit jejich vývoj a vliv na mezinárodní obchodněprávní vztahy a prostřednictvím tohoto nastínit možný budoucí vývoj. Autoři se zamýšlejí i nad tím, zda vzhledem $\mathrm{k}$ rychlému technologickému pokroku je současný desetiletý cyklus revize doložek INCOTERMS vhodný nebo zda se jedná o príliš dlouhou dobu. $Z$ nových trendů autoři poukazují na nové typy dopravy, především bezpilotní drony, dále pokračující trend transparentního a bezpečného logistického řetězce.

\section{NEUE HERAUSFORDERUNGEN INNERHALB DER INCOTERMS VOR DEM HINTERGRUND IHRER HISTORISCHEN ENTWICKLUNG}

INCOTERMS-Bedingungen sind international anerkannte Lieferungsbestimmungen. Ihr Vorteil besteht in Verständlichkeit und einer einförmigen Interpretation seitens der verhandelnden Parteien. Sie können leicht in den Vertrag eingegliedert werden. Ein weiterer unbestreitbarer Vorteil besteht in der regelmäßigen Aktualisierung. Die individuellen Aktualisierungen reflektieren die Trends im internationalen Handel und verdeutlichen oder widerrufen bestehende Bestimmungen oder führen bei Bedarf neue Bestimmungen ein. Das Ziel dieses Artikels besteht in der Bewertung der Entwicklung der INCOTERMSBestimmungen im Hinblick auf ihre historische Entwicklung und auf ihre Auswirkung auf internationale Handelsgesetzbestimmungen. Dadurch sollen mögliche zukünftige Entwicklungen skizziert werden. Die Autoren ziehen auch in Betracht, ob der bestehende Zehnjahreszyklus der Revision der INCOTERMS-Bestimmungen im Hinblick auf den raschen technologischen Prozess noch immer am Platze oder aber ein zu langer Zeitraum ist. Innerhalb der neuen Trends weisen die Autoren auf neue Typen des Transports hin, hauptsächlich auf die Verwendung unbemannter Drohnen, und auf den kontinuierlichen Trend einer transparenten und sicheren Logistikkette.

\section{NOWE WYZWANIA INCOTERMS NA TLE ICH HISTORYCZNEGO ROZWOJU}

Warunki INCOTERMS są uznanymi na całym świecie klauzulami dostawy. Ich zaletą jest zrozumiałość i jednolita interpretacja przez strony umowy, a także łatwe włączenie do umowy. Niewątpliwą zaletą jest ich regularna aktualizacja. Poszczególne aktualizacje odzwierciedlają trendy w międzynarodowej praktyce gospodarczej, a zatem w zależności od potrzeb doprecyzowują lub uchylają istniejące klauzule lub wprowadzają nowe. Celem artykułu jest ocena rozwoju klauzul INCOTERMS na bazie ich historycznego rozwoju i wpływu na międzynarodowe stosunki handlowe, a poprzez to nakreślenie możliwych kierunków rozwoju w przyszłości. Autorzy zastanawiają się również nad tym, czy wobec szybkiego postępu technologicznego obecny dziesięcioletni cykl rewizji klauzul INCOTERMS jest właściwy, czy też nie jest on zbyt długi. Wśród nowych trendów autorzy wskazują na nowe rodzaje transportu, zwłaszcza bezzałogowe drony, oraz utrzymującą się tendencję do tworzenia przejrzystego i bezpiecznego łańcucha logistycznego. 